\title{
Sistem Informasi Pemesanan Alat Pesta dan Katering Berbasis Android
}

\author{
Natal Nadapdap ${ }^{1}$, Desinta Purba ${ }^{2}$ \\ ${ }^{1,2}$ Universitas Katolik Santo Thomas Medan, Jl. Setiabudi No. 479 F. Tanjungsari, Medan, Indonesia
}

\section{ARTICLE INFORMATION}

Received: September, 20, 2020

Revised: September, 29, 2020

Available online: Oktober,31 2020

\section{KEYWORDS}

Five words maximum, comma separated

ANDROID, ALAT PESTA DAN CATERING, SISTEM INFORMASI PEMESANAN

Phone: +62 813-6206-9808

E-mail: nadapdapnatal40@gmail.com

\begin{abstract}
A $\quad$ B $\quad \mathbf{S}$ T $\mathbf{R}$ A $\mathbf{K}$
Aturan pelayanan Grace Teratak diawali dengan pemesanan teratak, katering, kemudian konsumen menunggu hingga pesanan diterima. Permasalahan yang terjadi di Grace Teratak adalah Sistem pemesanan yang dilakukan belom bisa melakukan pemesan melaui android. Maka perlunya dibuat sistem informasi pemesanan alat pesta dan katering berbasis android. Untuk dapat memudakan masysarakat dalam pencarian sewa teratak dan katering. Keuntungan dalam mengguunakan pemesanan teratak dan katering, masyarakat tidak perlu mendatangi pemilik teratak dan katering, masyarakat serta mempermudah dalam pencarian pemesanan alat pesta dan katering, dan lebih efesien dibandikan harus mendantangi nya lagi. Informasi mengenai Grace Teratak masih kurang diketahui masyarakat khususnya yang sering mengunakan akses internet dan yang ingin melakukan pemesanan catering, alat pesta secara online. Sistem informasi pemesanan yang masih bersifat manual sehingga untuk mendapatkan informasinya masyarakat harus datang ke Grace Teratak. Dengan memanfaatkan teknologi internet informasi-informasi yang ada di Grace Teratak bisa didapatkan dengan mudah dan juga dapat mempermudah masyarakat memesan alat pesta dan catering. Berdasarkan hasil analisa pada penelitian ini penulis mengunakan metode pengembangan perangkat lunak menggunakan ERD (Entity Relationship Diagram) dan UML (United Modelling Language) sedangkan MYSQL sebagai server database, PHP, Javascript, Ajax, Java, Html, CSS, android yang digunakan membuat Program, Dreamweaver, xampp, android studio, Photoshop, software yang digunakan untuk membangun Sistem tersebut.
\end{abstract}

\section{PENDAHULUAN}

Grace Teratak merupakan suatu usaha mandiri yang bergerak dibidang jasa penyewaan alat-alat pesta dan pemesanan katering di Kota kisaran. Saat ini teratak telah berdiri selama kurang lebih 10 tahun. Pada awalnya usaha ini hanya melayani jasa penyewaan teratak. Perusahaan yang beralamat di Jalan Desa Gajah,Dusun VIII kisaran ini, kini telah mulai berkembang, tidak hanya menyewakan teratak, tetapi juga menyediakan layanan musik, mobil penggantin, papan bunga, photobooth, tenda pesta, melayani jasa catering dan lain-lainnya [1].

Berdasarkan hasil pengamatan dan wawancara dengan pemilik Teratak pada bulan Desember tahun 2018, diketahui bahwa terjadi beberapa permasalahan pada transaksi penyewaan alat pesta dan pemesanan catering dengan pelanggan. Data setiap pelanggan yang menginginkan jasa masih disimpan dengan cara mencatatnya di sebuah buku. Begitu juga dengan data penyewaan alat pesta dan pemesanan catering yang dinginkan oleh pelanggan. Hal ini menimbulkan adanya resiko kesalahan pencatatan dan kehilangan data. Permasalahan lain yang terjadi adalah keterlambatan memperoleh informasi mengenai ketersediaan aset perlengkapan pesta yang dimiliki sesuai jadwal acara pelanggan.

Sistem informasi adalah sekumpulan komponen yang saling berhubungan, mengumpulkan, memproses, menyimpan, dan mendistribusikan informasi untuk menunjang pengambilan keputusan dan pengawasan dalam suatu organisasi[2]-[5].

Dalam pengertian yang umum, pada dasarnya sewa dapat diartikan sebagai harga yang dibayar atas penggunaan tanah dan faktorfaktor produksi lainnya yang jumlah penawarannya tidak dapat ditambah. Dalam pembicaraan sehari-hari sewa pada umumnya diartikan sebagai pembayaran yang dilakukan suatu keluarga ke atas rumah yang disewanya, atau pembayaran seorang pengusaha atas bangunan atau toko milik orang lain yang digunakannya [6]. Arti sewa dalam pembicaraan sehari-hari tersebut tidak sama dengan pengertian sewa secara umum. Karena sewa rumah, gedung atau yang lainnya tersebut telah meliputi bunga yang dibayarkan kepada modal yang digunakan untuk mendirikan bangunan-bangunan tersebut [7], [8].

Android adalah sistem operasi berbasis Linux yang dirancang untuk perangkat seluler layar sentuh seperti telepon pintar dan komputer tablet. Android awalnya dikembangkan oleh Android, Inc., dengan dukungan finansial dari Google, yang kemudian membelinya pada tahun 2005. Sistem operasi ini dirilis secara resmi pada tahun 2007, bersamaan dengan didirikannya Open Handset Alliance, konsorsium dari perusahaan-perusahaan perangkat keras, perangkat lunak, dan telekomunikasi yang bertujuan untuk memajukan standar terbuka perangkat seluler 


\section{METODE PENELITIAN}

Adapun metodologi penelitian penelitian ini adalah sebagai berikut [9]:

a. Penelitian Kepustakaan (Library Research) yaitu dengan menggunakan buku- buku program-program aplikasi dan media internet yang berhubungan dengan permasalahan yang akan dibahas dalam penelitian.

b. Penelitian lapangan (fileld Research) yang dengan mendapatkan data langsung dari bagian pengajaraan data-data yang diperlukan dalam penelitian.

c. Pencarian internet (internet searching). Yaitu dengan mendapatkan data yang diperoleh dari hasil pencarian internet yang bersumber dari jurnal ilmiah online.

d. Observasi, yaitu teknik pengumpulan data melaui wawancara langsung sama pemilik usaha teratak

\section{HASIL DAN PEMBAHASAN}

\subsection{Perancangan Sistem}

Perancangan sistem merupakan pendefinisian dari kebutuhan-kebutuhan fungsional dan persiapan untuk rancang bangun implementasi menggambarkan bagaimana suatu sistem dibentuk. Perancangan sistem dibuat berdasarkam masukan dari hasil analisa untuk menyelesaikan permasalahan yang ada pada tahap analisa [10].

\subsection{Use case Diagram}

Use Case menggambarkan external view dari sistem yang akan dibuat modelnya, komponen pembentuk diagram use case adalah [11]:

a. Aktor (actor), menggambarkan pihak-pihak yang berperan dalam sistem.

b. Use case, aktivitas yang disiapkan oleh bisnis/sistem

c. Hubungan (link), aktor mana saja yang terlibat dalam use case ini

Use case diagram akan memperlihatkan bagaimana peranan setiap actor dalam interaksi dengan sistem. Use case diagram untuk sistem yang akan dikembangkan terdiri dari tiga bagian yaitu sebagai berikut:

\section{a. Use Case Diagram Admin}

Use case diagram admin akan menjelaskan kegiatan yang dapat dilakukan oleh aktor admin dalam sistem yang akan dibangun. Use case diagram admin dapat dilihat seperti pada Gambar 1 di bawah ini.

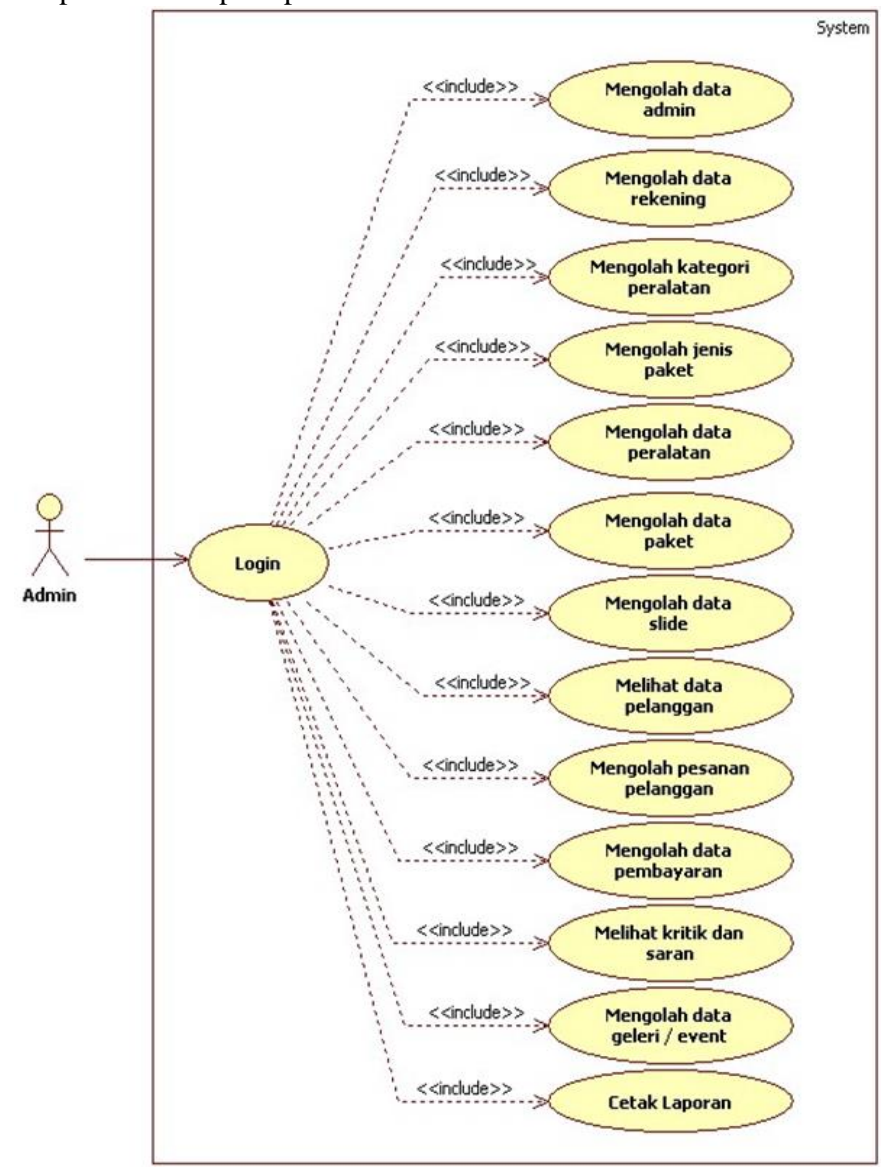

Gambar 1. Use Case Diagram Admin 


\section{b. Use Case Diagram Pelanggan}

Use case diagram pelanggan akan menjelaskan kegiatan yang dilakukan oleh aktor pelanggan dalam sistem yang akan dibangun. Use case diagram pelanggan dapat dilihat seperti pada Gambar 2 di bawah ini:

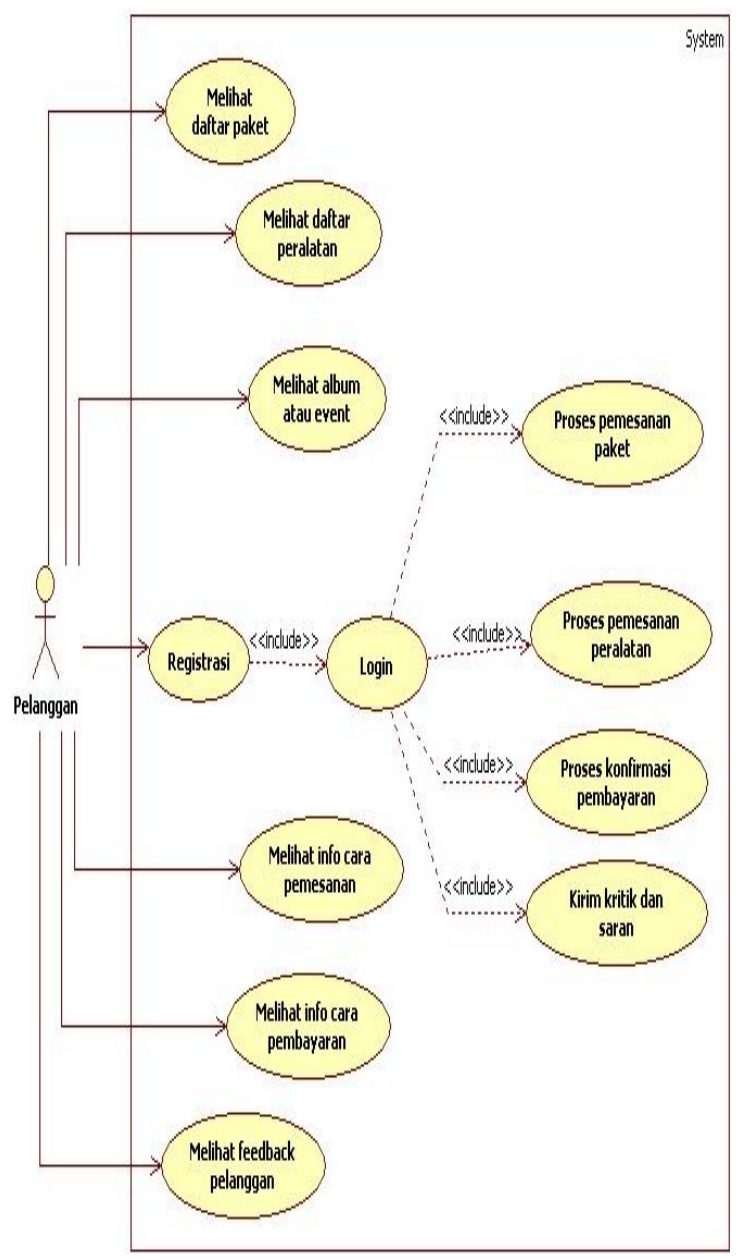

Gambar 2. Use Case Diagram Pelanggan

\section{c. Activity Diagram}

1. Activity Diagram Login Admin

Activity diagram login admin akan mejelaskan aliran aktivitas antara admin dan sistem pada saat proses login kedalam sistem. Activity diagram login admin dapat dilihat seperti pada Gambar 3 di bawah ini

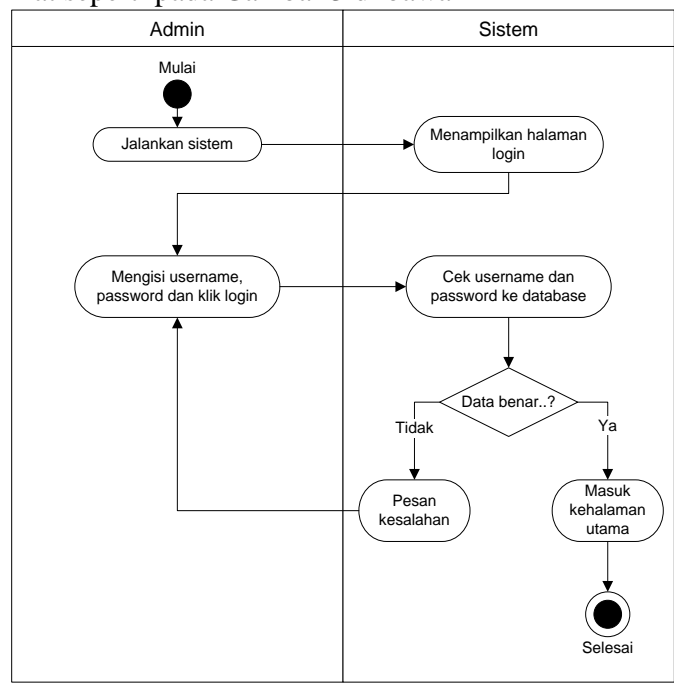

Gambar 3. Activity Diagram Login Admin 
2. Activity Diagram Pengolahan Data Admin Activity diagram pengolahan data admin menjelaskan aliran aktivitas antara admin dan sistem pada saat mengolah data admin. Activity diagram pengolahan data admin dapat dilihat seperti pada Gambar 4 di bawah ini.

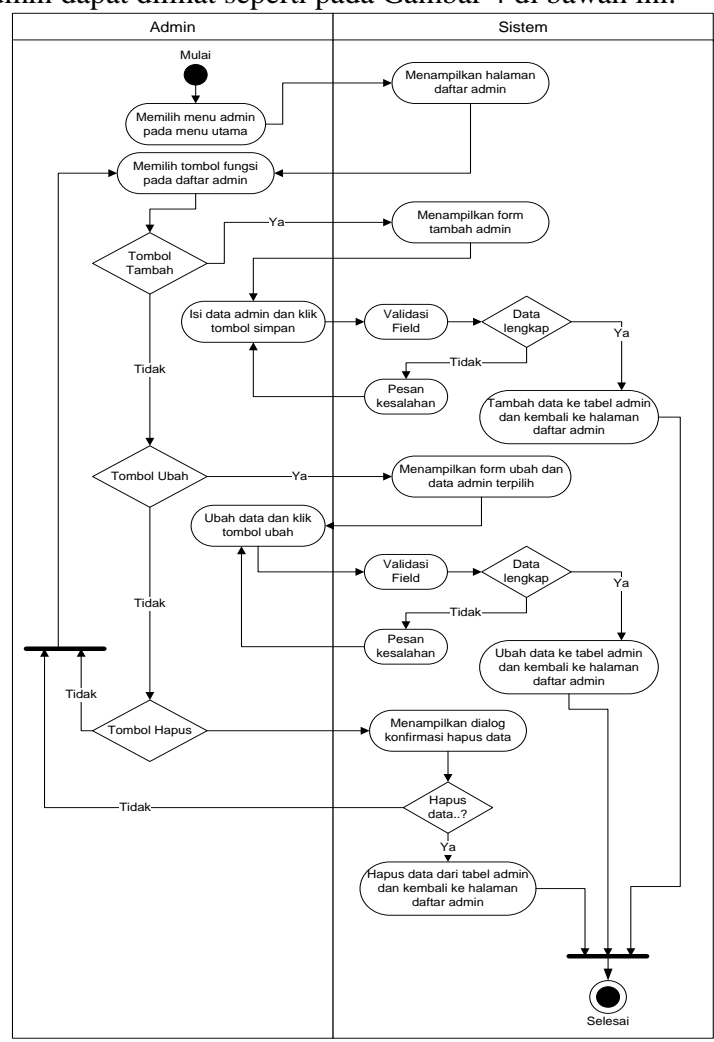

Gambar 4 Activity Diagram Pengolahan Data Admin

\section{d. Class Diagram}

Pemodelan data digambarkan dalam bentuk Class Diagram yang menjelaskan visualisasi dari struktur kelas-kelas yang nantinya akan digunakan sebagai panduan pada tahap implementasi perangkat lunak. Seperti halnya use case, berdasarkan fungsinya maka class diagram dibagi menjadi class diagram untuk aplikasi di client dan class diagram untuk pengolahan data di server. Untuk dapat menjelaskan lebih detail mengenai atribut dan method yang terdapat didalam masing-masing class diagram, maka akan dijelaskan seperti pada Gambar 5 di bawah ini.

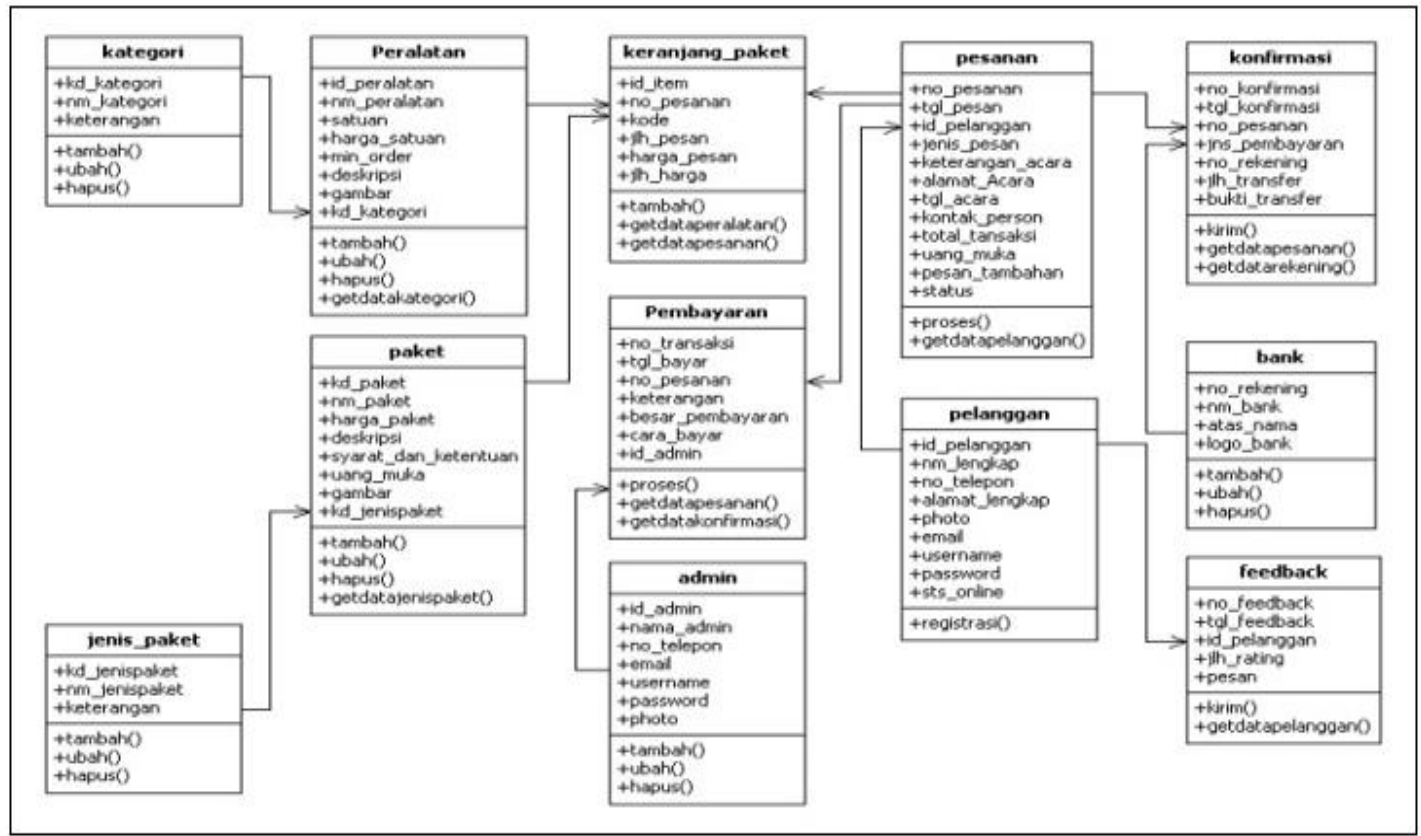

Gambar 5. Class Diagram 


\section{e. Relasi Antar Tabe}

Bentuk relasi atau hubungan antar table pada database yang dibangun dapat dilihat seperti pada Gambar 6 di bawah ini.

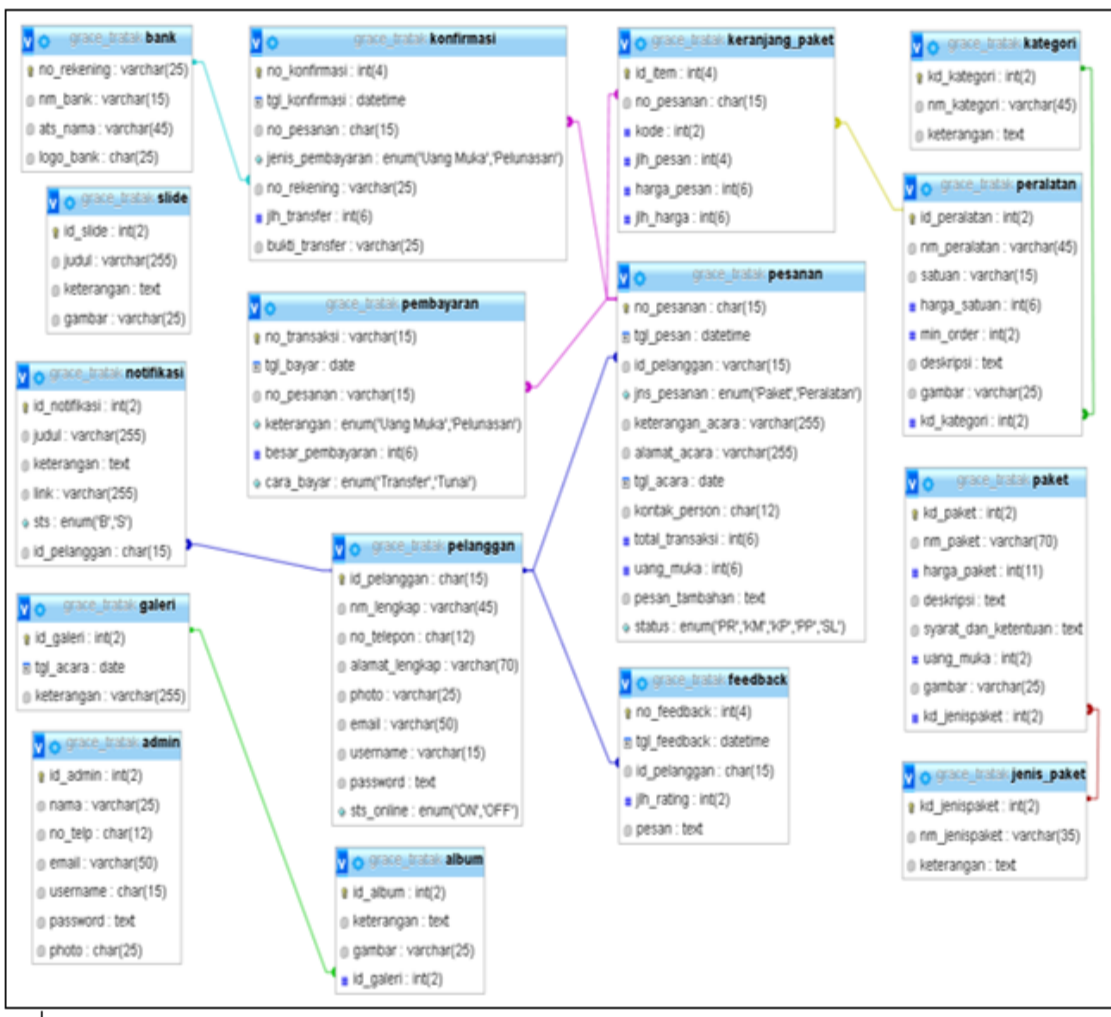

Gambar 6. Relasi Antar Tabel

\section{f. Perancangan Interface Pelanggan}

1. Rancangan Halaman Utama Sistem

Halaman ini merupakan tampilan yang pertama kali muncul saat pengunjung membuka aplikasi apk yang akan dibangun. Dengan halaman utama, maka setiap pengunjung dapat mengakses halaman-halaman lain. Bentuk dari rancangan halaman utama dapat dilihat seperti pada Gambar 7 di bawah ini.

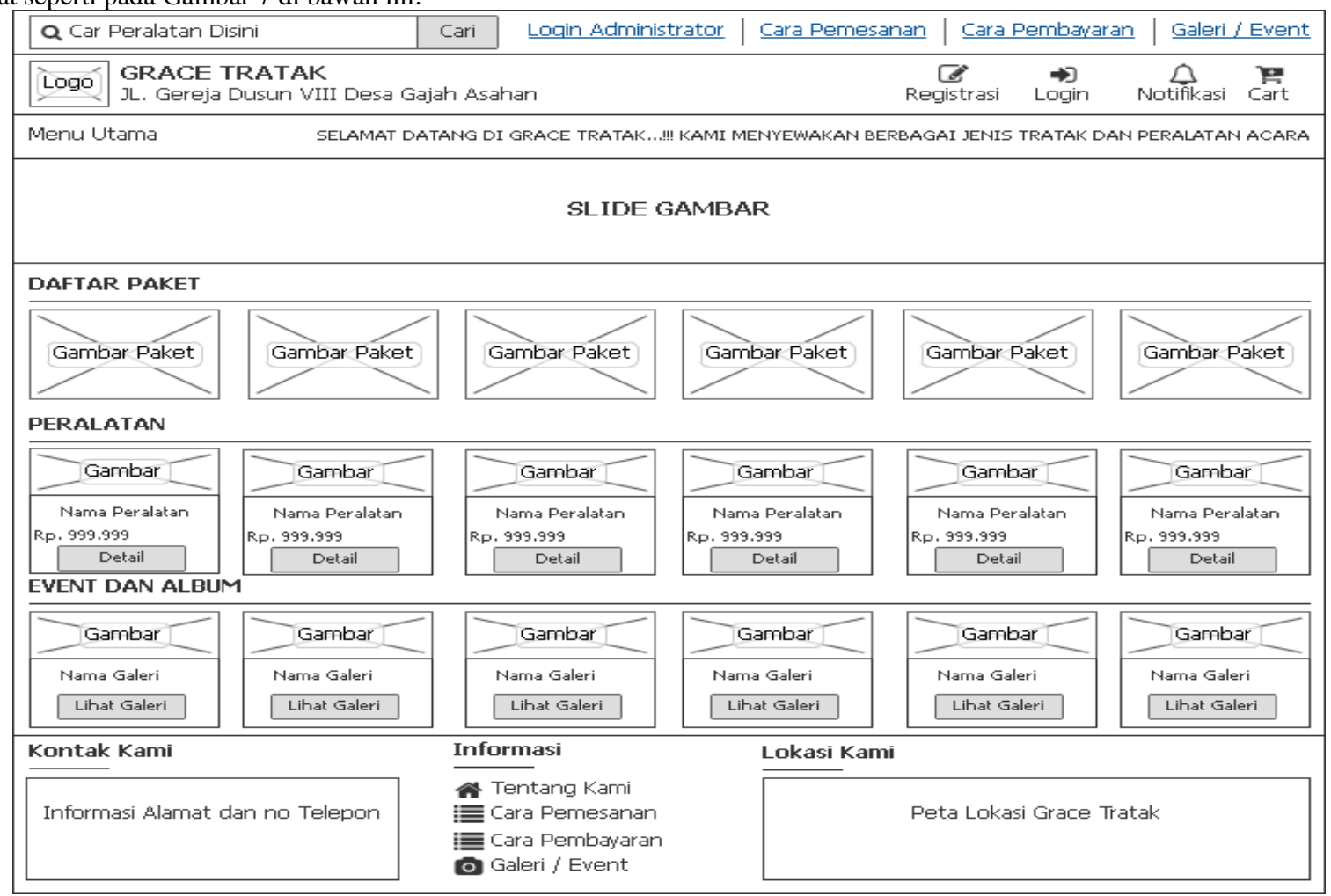

Gambar 7. Rancangan Halaman Utama Sistem 
2. Rancangan Halaman Detail Paket

Pada halaman ini akan ditampilkan informasi detail paket yang dipilih oleh pengunjung. Adapun bentuk halaman detail paket dapat dilihat seperti pada Gambar 8 di bawah ini.

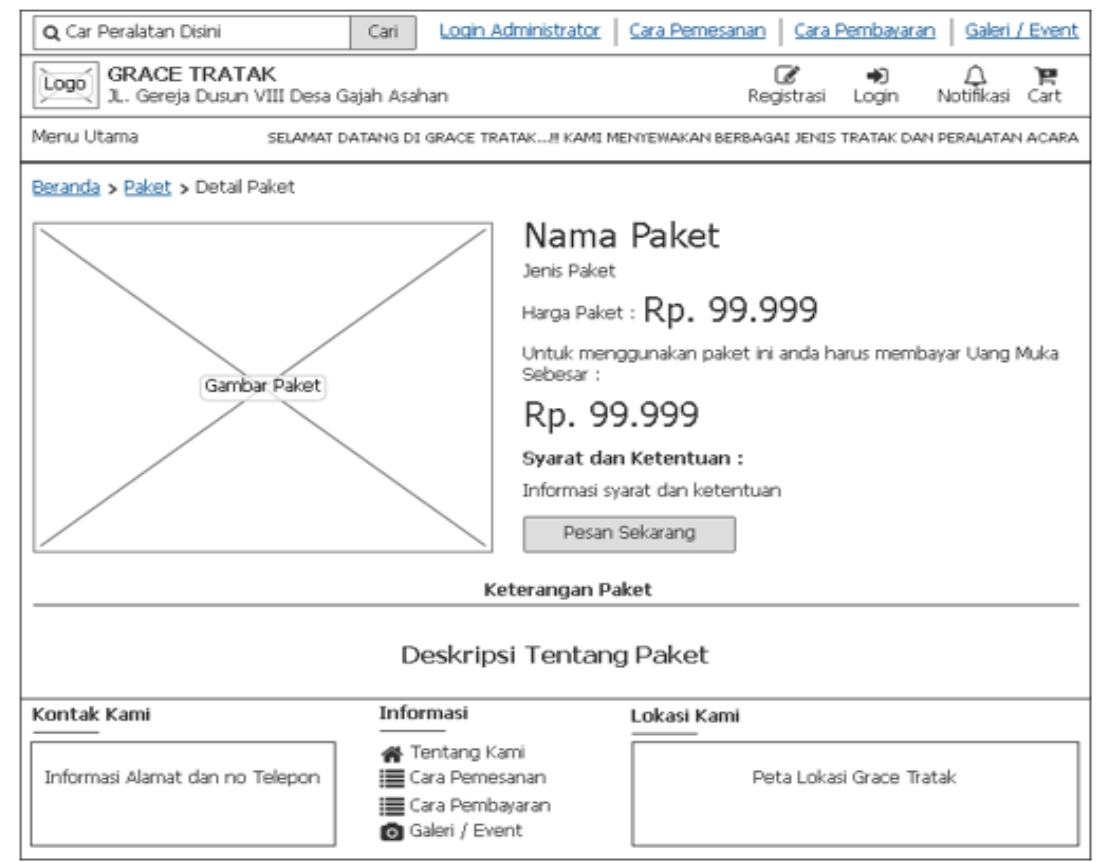

Gambar 8. Rancangan Halaman Detail Paket

g. Perancangan Output

1. Rancangan Output Daftar Perlatan

Rancangan output daftar peralatan merupakan salah satu hasil sistem yang akan dibangun. Daftar peralatan berfungsi untuk menampilkan secara detail informasi mengenai peralatan. Rancangan daftar peralatan dapat dilihat seperti pada Gambar 9 di bawah ini.

\begin{tabular}{|c|c|c|c|c|c|}
\hline \multicolumn{6}{|c|}{$\begin{array}{l}\text { GRACE TERATAK } \\
\text { N BERBAGAIJENIS TRATAK DAN PERALATAN ACARA } \\
\text { usun VIII Desa Gajah Kecamatan Meranti, Kabupaten Asahan } \\
\text { Kode Pos : } 21264 \text { - No Telepon : (+6121) } 5703303\end{array}$} \\
\hline \multicolumn{6}{|c|}{ DAFTAR PERALATAN } \\
\hline $\mathrm{N}_{0}$ & Nama Peralatan & Kategori & Harga Satuan & Minimal Order & Deskripsi \\
\hline 99 & 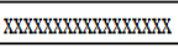 & 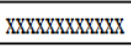 & Rp. 99.999 & 999 & 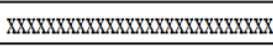 \\
\hline 99 & $x x x x x x x x x x x x x x x x x x x$ & $x x x x x x x x x x x x x$ & Rp. 99.999 & 999 & $x \mathrm{x} x \mathrm{x} x \mathrm{x} \mathrm{x} \mathrm{x} \mathrm{x} \mathrm{x} \mathrm{x} \mathrm{x} \mathrm{x} \mathrm{x} \mathrm{x} \mathrm{x} \mathrm{x} \mathrm{x} \mathrm{x} \mathrm{x} \mathrm{x} \mathrm{x} \mathrm{x} \mathrm{x} \mathrm{x} \mathrm{x}$ \\
\hline 99 & $x \mathrm{xx} x \mathrm{x} x \mathrm{x} \mathrm{x} \mathrm{x} \mathrm{x} \mathrm{x} \mathrm{x} \mathrm{x} \mathrm{x} \mathrm{x} \mathrm{x} \mathrm{x}$ & $x \mathrm{xx} x \mathrm{x} \mathrm{x} \mathrm{x} \mathrm{x} \mathrm{x} \mathrm{x} \mathrm{x}$ & Rp. 99.999 & 999 & 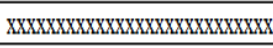 \\
\hline 99 & 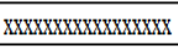 & 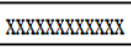 & Rp. 99.999 & 999 & 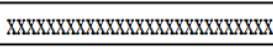 \\
\hline 99 & $x \mathrm{x} x \mathrm{x} x \mathrm{x} \mathrm{x} \mathrm{x} \mathrm{x} \mathrm{x} \mathrm{x} \mathrm{x} \mathrm{x} \mathrm{x} \mathrm{x} \mathrm{x} \mathrm{x}$ & $x x x x x x x x x x x x$ & Rp. 99.999 & 999 & 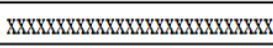 \\
\hline & & & & & 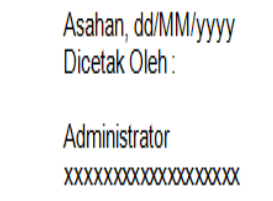 \\
\hline
\end{tabular}

Gambar 9. Rancangan Output Daftar Peralatan

2. Rancangan Output Daftar Paket

Daftar paket berfungsi untuk menampilkan daftar paket pesta. Rancangan daftar paket dapat dilihat seperti pada Gambar 10 di bawah ini. 


\begin{tabular}{|c|c|c|c|c|c|}
\hline \multicolumn{6}{|c|}{$\begin{array}{c}\text { GRACE TERATAK } \\
\text { MENYEWAKAN BERBAGAI JENIS TRATAK DAN PERALATAN ACARA } \\
\text { JL. Gereja Dusun VIII Desa Gajah Kecamatan Meranti, Kabupaten Asahan } \\
\text { Kode Pos : } 21264 \text { - No Telepon : (+6121) } 5703303\end{array}$} \\
\hline \multicolumn{6}{|c|}{ DAFTAR PAKET } \\
\hline $\mathrm{N}_{0}$ & Nama Paket & Jenis Paket & Harga Paket & Uang Muka & Deskripsi \\
\hline 99 & $x x x x x x x x x x x x x x x x x$ & $x x x x x x x x x x x x$ & Rp. 99.999 & Rp. 99.999 & $\mathrm{xx} x \mathrm{x} x \mathrm{x} \mathrm{x} \mathrm{x} \mathrm{x} \mathrm{x} \mathrm{x} \mathrm{x} \mathrm{x} \mathrm{x} \mathrm{x} \mathrm{x} \mathrm{x} \mathrm{x} \mathrm{x} \mathrm{x} \mathrm{x} \mathrm{x}$ \\
\hline 99 & 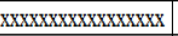 & 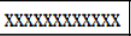 & Rp. 99.999 & Rp. 99.999 & 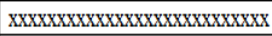 \\
\hline 99 & $x x x x x x x x x x x x x x x x x$ & $x x x x x x x x x x x x$ & Rp. 99.999 & Rp. 99.999 & 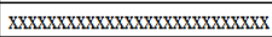 \\
\hline 99 & 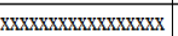 & $x x x x x x x x x x x x$ & Rp. 99.999 & Rp. 99.999 & $\mathrm{xxx} x \mathrm{x} x \mathrm{x} x \mathrm{x} \mathrm{x} \mathrm{x} \mathrm{x} \mathrm{x} \mathrm{x} \mathrm{x} \mathrm{x} \mathrm{x} \mathrm{x} \mathrm{x} \mathrm{x} \mathrm{x} \mathrm{x} \mathrm{x} \mathrm{x} \mathrm{x}$ \\
\hline \multirow[t]{3}{*}{99} & 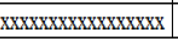 & 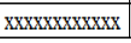 & Rp. 99.999 & Rp. 99.999 & 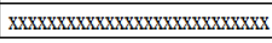 \\
\hline & & & & & $\begin{array}{l}\text { Asahan, dd/MM/yyyy } \\
\text { Dicetak Oleh: }\end{array}$ \\
\hline & & & & & $\begin{array}{l}\text { Administrator } \\
x x x x x x d x x x x x x x x x x x x x\end{array}$ \\
\hline
\end{tabular}

Gambar 10. Rancangan Output Daftar Paket

3. Rancangan Output Laporan Pesanan Paket

Rancangan output laporan pesanan paket merupakan salah satu hasil sistem yang akan dibangun. Laporan pesanan paket berfungsi untuk menampilkan daftar pesanan pelanggan berdasarkan periode tertentu dan dikelompokkan berdasarkan paket. Rancangan laporan pemesanan paket dapat dilihat seperti pada Gambar 11 di bawah ini.

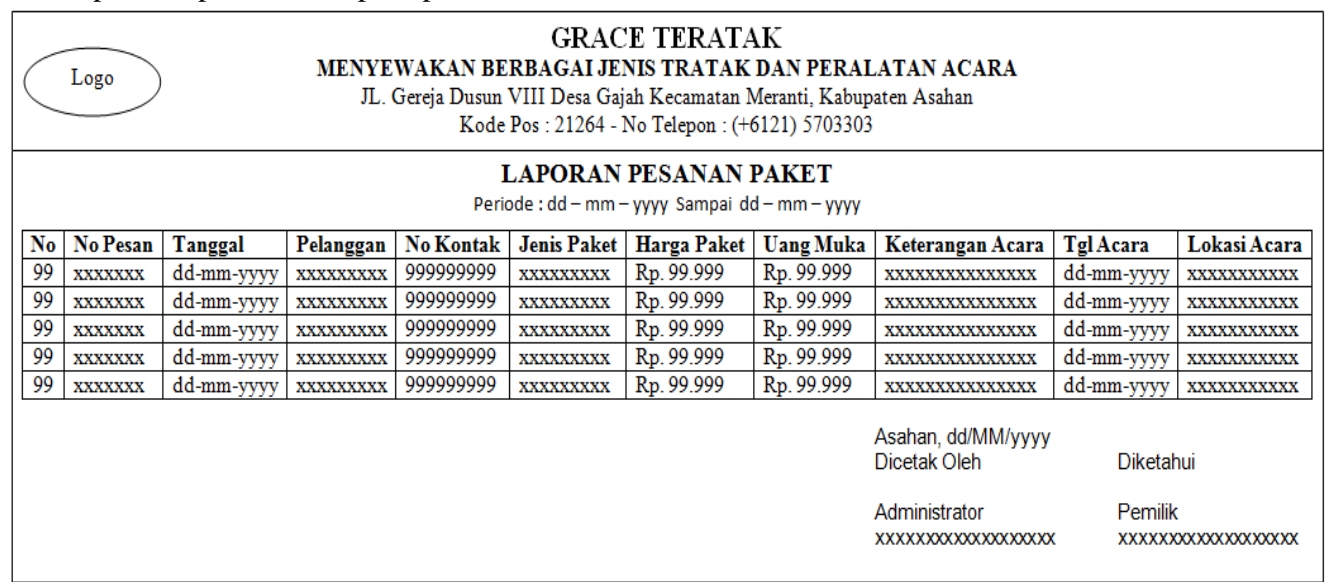

Gambar 11. Rancangan Output Laporan Pesanan Paket

4. Rancangan Output Laporan Pesanan Peralatan

Rancangan output laporan pesanan peralatan merupakan salah satu hasil sistem yang akan dibangun. Laporan pesanan peralatan berfungsi untuk menampilkan daftar pesanan pelanggan berdasarkan periode tertentu dan dikelompokkan berdasarkan peralatan. Rancangan laporan pesanan peralatan dapat dilihat seperti pada Gambar 12 di bawah ini.

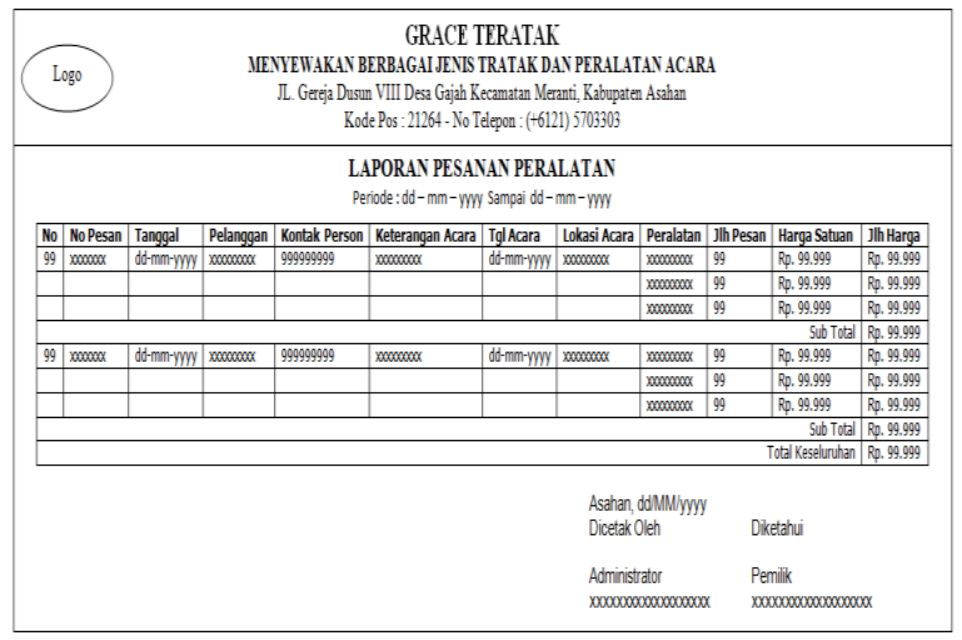

Gambar 12. Rancangan Output Laporan Pesanan Peralatan 
5. Rancangan Output Laporan Pembayaran

Rancangan output laporan pembayaran merupakan salah satu hasil sistem yang akan dibangun. Laporan pembayaran berfungsi untuk menampilkan data pembayaran pesanan pelanggan. Rancangan laporan pembayaran dapat dilihat seperti pada Gambar 13 di bawah ini.

\begin{tabular}{|c|c|c|c|c|c|c|c|c|c|c|}
\hline \multicolumn{11}{|c|}{$\begin{array}{c}\text { GRACE TERATAK } \\
\text { MENYEWAKAN BERBAGAI JENIS TRATAK DAN PERALATAN ACARA } \\
\text { JL. Gereja Dusun VIII Desa Gajah Kecamatan Merantit, Kabupaten Ashan } \\
\text { Kode Pos : } 21264 \text { - No Telepon : (+6121) } 5703303\end{array}$} \\
\hline \multicolumn{11}{|c|}{$\begin{array}{l}\text { LAPORAN PEMBAYARAN } \\
\text { Periode : } d d \text { - mm - ywy Sampai dd - mm- ywy }\end{array}$} \\
\hline No & No Pembayaran & \begin{tabular}{|l|} 
Tanggal \\
\end{tabular} & Keterangan & \begin{tabular}{|l} 
Pelanggan \\
\end{tabular} & \begin{tabular}{|l|} 
No Kontak \\
\end{tabular} & Ket. Acara & \begin{tabular}{|l|} 
Tgl Acara \\
\end{tabular} & \begin{tabular}{|l|l|} 
Lokasi Acara \\
\end{tabular} & \begin{tabular}{|l} 
Total Biaya \\
\end{tabular} & Jlh pembayaran \\
\hline 99 & $\operatorname{sen} x=x$ & dd-mm-yyyy & $\operatorname{mocococosx}$ & 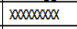 & \begin{tabular}{|l|l|l}
999999999999 \\
\end{tabular} & $\operatorname{xocos00000x} x$ & dd-mm-yyyy & $\operatorname{sencosex}$ & \begin{tabular}{|l|l|} 
Rp. 99.9999 \\
\end{tabular} & Rp. 99.999 \\
\hline 99 & $\operatorname{scosecox} x$ & dd-mm-yyyy & $200000000 x$ & 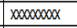 & 999999999999 & $x \operatorname{coscoxoxxy} x$ & dd-mm-yyyy & $\operatorname{coscoscoxax}$ & \begin{tabular}{|l|l|} 
Rp. 99.9999 \\
\end{tabular} & \begin{tabular}{|l|l|}
$R p .99 .9999$ \\
\end{tabular} \\
\hline 99 & $\cos 0000 x$ & $d d-m m-y y y y$ & $\operatorname{xoc000000x} x$ & $\operatorname{senc00000x} x$ & 999999999999 & $x \cos 000000 x x$ & $d d-m m-y y y y$ & $\operatorname{sen} x \cos x=x$ & \begin{tabular}{|l|l|} 
Rp. 99.9999 \\
\end{tabular} & Rp. 99.999 \\
\hline 99 & $\operatorname{coscosx}$ & dd-mm-yyyy & $2 x 0000000 x$ & $x \cos x=0 x x$ & 9999999999999 & $\operatorname{coscoscosx} x$ & dd-mm-yyyy & $\cos x \cos x \cos x$ & Rp. 99.999 & Rp. 99.999 \\
\hline 99 & $000000 x$ & dd-mm-yyyy & $1000000000 x$ & 5000000000 & 9999999999 & $x+00000000 x$ & dd-mmm-yyyy & $1000000000 x$ & Rp. 99.999 & Rp. 99.999 \\
\hline 99 & $\cos x=00 x$ & dd-mm-yYYY & $1000000000 x$ & $1000000000 x$ & 9999999999 & $x+00000000 x$ & dd-mmm-yyy & 100000000x & \begin{tabular}{|l|l|} 
Rp. 99.999 \\
\end{tabular} & Rp. 99.999 \\
\hline \multicolumn{11}{|c|}{$\begin{array}{l}\text { Asahan, dd/MM/yyyy } \\
\text { Dicetak Oleh }\end{array}$} \\
\hline \multicolumn{11}{|c|}{ 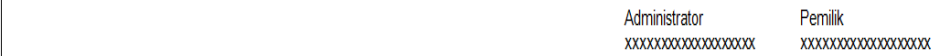 } \\
\hline
\end{tabular}

Gambar 13. Rancangan Output Laporan Pembayaran

\section{KESIMPULAN}

Pada penelitian, penulis membuat sesuatu sistem pemesanan alat pesta dan katering berbasis android. Berdasarkan pembahasan dan evaluasi dari bab-bab sebelumnya, maka dapat diambil beberapa kesimpulan yaitu sebagai berikut:

a. Sistem pemesanan alat pesta dan katering tidak perlu mendatangi pemilik alat pesta dan katering.

b. Sistem pemesanan alat pesta dan katering online di harapkan dapat membantu masyarakat serta mempermudah masyarakat dalam pencarian alat pesta dan katering berbasis android.

c. Sistem pemesanan alat pesta dan katering online lebih efesien dibandingkan dengan pemesanan manual.

d. Sistem pemesanan alat pesta dan katering ini dapat digunakan sebagai wadah bagi masyarakat untuk memesan alat pesta.

\section{DAFTAR PUSTAKA}

[1] M. Y. Panjaitan and R. Damanik, "Sistem Informasi Catholic Center Medan Berbasis Web," MEANS (Media Inf. Anal. dan Sist., vol. 2, no. 2, pp. 134-138, Jan. 2018, doi: 10.17605/JMEANS.V2I2.150.

[2] I. Taufik, "Sistem Informasi Catatan Perkuliahan Mahasiswa pada STMIK Pelita Nusantara Medan," MEANS (Media Inf. Anal. dan Sist., vol. 4, no. 1, pp. 16-19, 2019.

[3] J. O. Sembiring and S. Pakpahan, "Sistem Informasi Pemesanan Dan Penjualan Barang pada Pintera Kreativ Berbasis Web," MEANS (Media Inf. Anal. dan Sist., vol. 2, no. 2, pp. 146-152, Jan. 2018, doi: 10.17605/JMEANS.V2I2.152.

[4] C. M. Saragih and R. Damanik, "Sistem Informasi Penerimaan Pendeta pada Kantor Pusat GKPS Berbasis Web," KakifikomKumpulan Artik. Karya Ilm. Fak. Ilmu Komput., vol. 01, no. 1, pp. 35-39, 2019.

[5] B. Das, E. Damanik, and W. Ginting, "Aplikasi Sistem Informasi Museum Negeri Provinsi Sumatera Utara Berbasis Android," KakifikomKumpulan Artik. Karya Ilm. Fak. Ilmu Komput., vol. 01, no. 2, pp. 67-72, 2019.

[6] I. Maulana and R. Ginanjar, "Sistem Informasi Manajemen Kost Berbasis Web," Inf. Syst. Appl., vol. 2, no. 1, Mar. 2017.

[7] H. Zakaria, "Perancangan Aplikasi Penjualan dan Penyewaan Mobil berbasis Web menggunakan Model Waterfall pada CV. Dhiyara Anugrah,” J. Inform. Universtias Pamulang, vol. 2, no. 4, pp. 184-180, 2017.

[8] E. C. Ramdhani and E. Sapitri, "Sistem Informasi Penyewaan Peralatan Event Organizer Berbasis Web pada PT . Adecon Jakarta," J. Pengbdian Kpd. Masy., vol. 1, no. 3, pp. 390-397, 2018, [Online]. Available: https://ejournal.bsi.ac.id/ejurnal/index.php/abdimas/article/view/4044/2512.

[9] Sugiyono, Metode Penelitian Kuantitatif, Kualitatif dan R\&D. Bandung: PT Alfabet, 2016.

[10] T. Limbong, "PERANCANGAN SISTEM INFORMASI KEHADIRAN MENGAJAR DOSEN," Pelita Inform. Inf. dan Inform., 2012.

[11] M. Destiningrum and Q. J. Adrian, "Sistem Informasi Penjadwalan Dokter Berbassis Web Dengan Menggunakan Framework Codeigniter (Studi Kasus: Rumah Sakit Yukum Medical Centre),” J. Teknoinfo, vol. 11, no. 2, p. 30, 2017, doi: 10.33365/jti.v11i2.24. 